\title{
Two new infraspecific taxa of Verbascum delphicum (Scrophulariaceae, Scrophularieae) from mainland Greece and the island of Evvia
}

\author{
Aris Zografidis' \\ I Institute of Biosciences and Applications, National Centre for Scientific Research Demokritos, Aghia Paraskevi, \\ Athens, Greece \\ Corresponding author: Aris Zografidis (azogra@bio.demokritos.gr)
}

Academic editor: E. Fischer | Received 6 September 2016 | Accepted 3 November 2016 | Published 10 November 2016

Citation: Zografidis A (2016) Two new infraspecific taxa of Verbascum delphicum (Scrophulariaceae, Scrophularieae) from mainland Greece and the island of Evvia. PhytoKeys 74: 107-122. doi: 10.3897/phytokeys.74.10381

\begin{abstract}
Verbascum delphicum Boiss. \& Heldr. subsp. cervi Zografidis (Scrophulariaceae, Scrophularieae) is described as a subspecies new to science and illustrated. It is narrowly distributed in the Greek National Park of Mt Parnitha (Attica, Greece) with a very small population size. The new subspecies is a seldom-collected taxon, previously overlooked and misidentified as consubspecific with the autonymous subspecies, an endemic of the island of Evvia (Greece). Also described in this study is a new variety of subsp. delphicum from Mt Ochi of southern Evvia.
\end{abstract}

\section{Keywords}

Verbascum, new subspecies, endangered taxon, Mt Parnitha

\section{Introduction}

Comprising more than 360 species, Verbascum L. (Scrophulariaceae) is the largest genus of the predominantly northern temperate tribe Scrophularieae Dumort. (= Verbasceae Dumort.) and is chiefly represented by rosulate, biennial or perennial herbs with yellow-flowered, thyrsic or racemose inflorescences (Fischer 2004; Oxelman et al. 2005). Although the genus is widely distributed in Eurasia and North Africa, species 
diversity is mostly concentrated in a region encompassing Anatolia, Caucasus, northwestern Iran, the Levant and the southern Balkans (Murbeck 1939). In Greece, Verbascum is among the 10 most species-rich and the 10 most range-restricted-rich genera with a total of 76 species and an endemism rate of 32\% (Dimopoulos et al. 2013).

Verbascum was extensively studied by the Swedish botanist Svante Murbeck who published two monographs on Verbascum and Celsia L. - now merged in Verbascum - and a series of two additional, supplementary and interpretative studies on the genus (Murbeck 1925; 1933; 1936; 1939). Since his era, several other species have been discovered and described, principally but not exclusively from Anatolia (AI-Hemaid 2001; Aytaç and Duman 2012; Bani et al. 2010; Çeçen et al. 2015; Davis 1951; 1952; Firat 2015; Greuter and Rechinger 1972; Huber-Morath 1939; 1949; 1955; 1960; 1965; 1967; 1971; 1973; 1974; 1975; 1976; 1979; 1981; 1983; Karavelioğullari 2015; Karavelioğullari et al. 2011; Karavelioğullari et al. 2004; Karavelioğulları et al. 2009; Karavelioğullari et al. 2008; Karavelioğullari et al. 2014; Kaynak et al. 2006; Parolly and Eren 2008; Parolly and Tan 2007; Ranjbar and Nouri 2015; Sotoodeh et al. 2015; Sotoodeh et al. 2016; Stefanova-Gateva 1979) and a modified classification system of "informal, partly artificial groups" has been utilized by Arthur Huber-Morath for the Turkish taxa (Huber-Morath 1978). Both taxonomies of Murbeck and of Huber-Morath are still widely cited and used today in studies of new species; however, it should be noted that a first assessment of molecular data suggests these schemes are non-natural and that the genus has potentially been subjected to taxonomic inflation (Ghahremaninejad et al. 2014).

Verbascum delphicum Boiss. \& Heldr. was discovered by Theodor von Heldreich on Mt Dirfi of the island of Evvia (West Aegean Islands, Greece) and was subsequently jointly described by himself and Edmond Boissier in Boissier's Diagnoses plantarum Orientalium novarum (Boissier 1856). The autonymous subspecies is a nemoral, shortlived perennial or biennial herb with often impressive, sizeable basal leaves. Knowing the taxon well from my excursions on the mountains of central and south Evvia I was surprised to find on Mt Parnitha (Attica, Sterea Ellas, mainland Greece) on May 2013 a small population of a closely related, yet distinct and undescribed as it appeared to be taxon. The population consisted of biennial plants with noticeably smaller and more or less differently shaped leaves than those of the insular $V$. delphicum. Inspection of the mainland population in the past recent years and comparison with the insular populations revealed some additional deviating traits for the taxon on Mt Parnitha. Taking into consideration overall morphology and the common habitat and phenology of the two taxa, as well as the phytogeographic connection between Sterea Ellas and Ins. Evvia, I propose that collectively the differences indicate distinction at the subspecies rank.

The new subspecies $V$. delphicum subsp. cervi Zografidis described and illustrated in this work was apparently overlooked and misidentified by Murbeck as consubspecific with subsp. delphicum based on material collected by Heldreich and Bassilios Tuntas from Mt Parnitha. The differences between the two subspecies are presented and discussed. A new, distinct variety of subsp. delphicum from Mt Ochi, south Evvia is also described. 


\section{Methods}

For the cultivated material current-year seeds were sown in early October (2013 \& 2015), in small pots filled with $\mathrm{Compo}^{\circ}$ Bio Anzucht- und Kräutererde substrate. Twoweeks old plants were individually transferred in plastic pots $7 \mathrm{~cm}$ of diameter and were transplanted every c. 8 weeks two additional times in successively larger plastic pots, 15 and $24 \mathrm{~cm}$ of diameter. The plants were kept outdoors, daily receiving 5 hours of direct sunlight on average, whereas the substrate was kept moist but not soggy.

Measurements were performed either with a common ruler or under a stereomicroscope (Zeiss, Stemi 2000-C) equipped with a camera and ImagePro software. Because the population size of the new subspecies is extremely small the measurements were either performed in situ without damaging the plants, or, when this was not feasible, only small plant-parts were collected for subsequent assessment under the stereomicroscope. In particular, two flower-clusters (glomerules) of the middle part of the inflorescence were removed from 20 individual plants i) at flowering and ii) at fruiting. Statistical significance was assessed with two-tailed T-tests for two independent means $(p<0.01)$ and two-tailed Mann-Whitney U-tests $(p<0.01)$.

\section{Taxonomy}

Verbascum delphicum Boiss. \& Heldr. subsp. cervi Zografidis, subsp. nov. urn:lsid:ipni.org:names:77158533-1

Figures 1, 2; Suppl. material 1

Diagnosis. subsp. cervi can be distinguished from subsp. dephicum by a combination of the following characters: lamina of larger rosette-leaves 6-22 × 3-11 cm (vs. 16-40 $\times 11-24), 1.5-3.7$ of length to width ratio (vs. 1.2-1.9), obtuse-cuneate at the base (vs. obtuse-truncate to cordate); indumentum of abaxial surface of rosette-leaves thinner; indumentum of adaxial surface of first-year mature rosette-leaves \pm harsh (vs. soft); stamen filaments greenish-white (vs. orange).

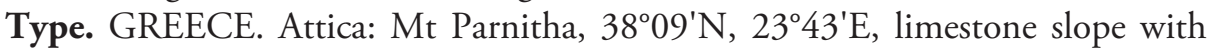
Abies cephalonica, $1100 \mathrm{~m}, 22$ June 2015, A. Zografidis 109. (Holotype: ATH, Isotype: ATHU)

Description. Monocarpic, eglandular- and minutely glandular-hairy biennial herb —or rarely short-lived perennial bicarpic — producing a well-branched taproot and a basal leaf-rosette in the first year of vegetative growth, followed by the production of additional rosette-leaves (in the same rosette) and an erect, terete, leafy flowering-stem in the second year of vegetative and reproductive growth. Eglandular hairs dendritic, $0.2-0.8 \mathrm{~mm}$ of length, more or less covering the whole aerial part of the plant; glandular hairs minute, sparse, present on leaves, bracts, bracteols and calyx segments, visible by microscopy; fully developed first-season rosettes yellowish- to brownish- and harshly-tomentose above, grayish- or yellowish- to brownish-, 


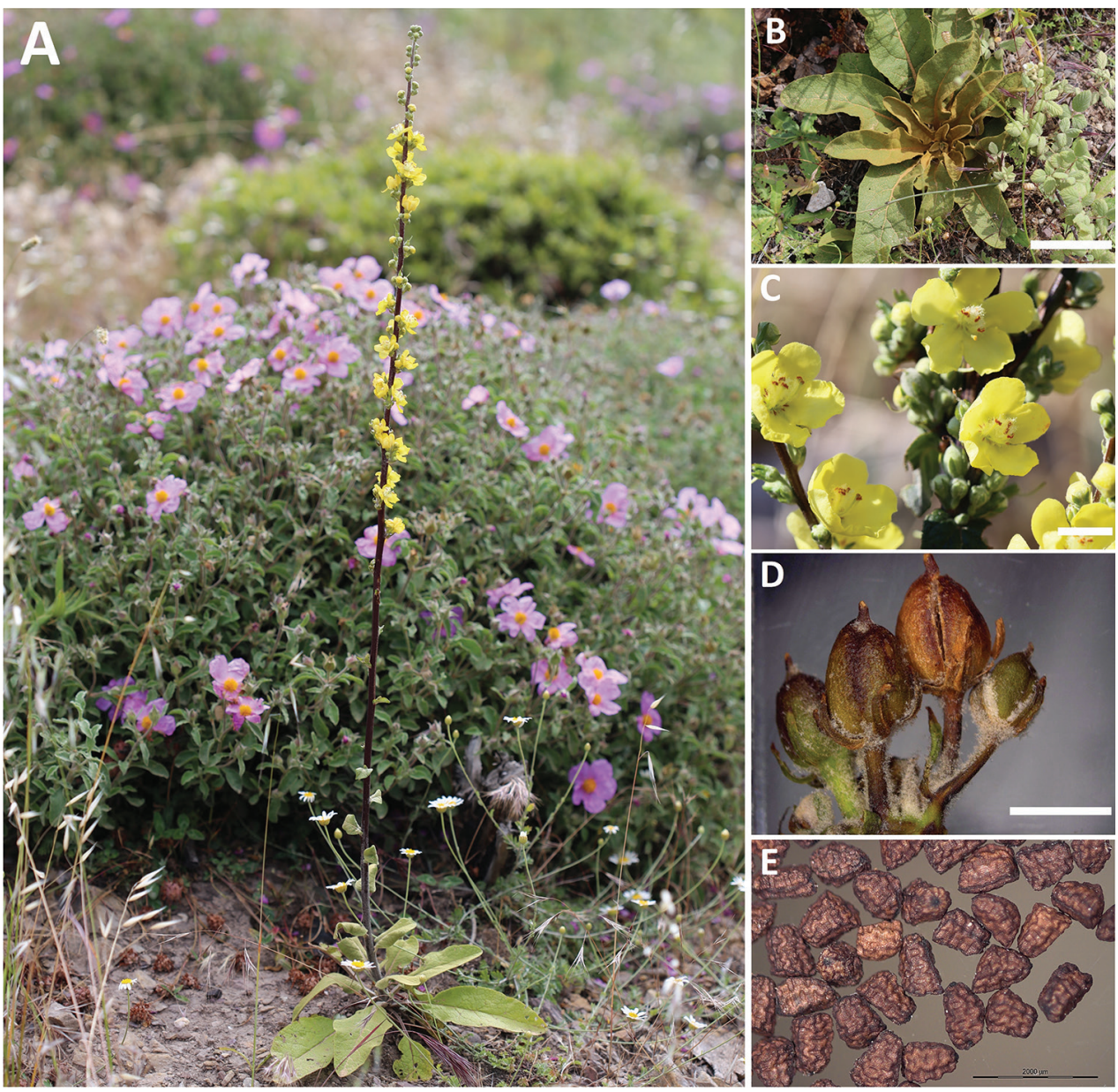

Figure I. Verbascum delphicum subsp. cervi Zografidis: A habit B first year mature leaf-rosette, bar $=10 \mathrm{~cm}$ C partial inflorescence, bar $=1 \mathrm{~cm} \mathbf{D}$ capsules, bar $=5 \mathrm{~mm} \mathbf{D}$ seeds, bar $=2 \mathrm{~mm}$.

and \pm harshly-tomentose beneath; rosette-leaves few to several (up to 50 in cultivated specimens), petiolate; petiole $1-10 \mathrm{~cm}$ of length; lamina ovate-elliptic to oblanceolate, 1.5-3.7 of length to width ratio, obtuse-cuneate at the base, crenate, obtuse at apex; larger leaf laminas 6-22 × 3-11 cm; second year mature rosette-leaves and lower cauline-leaves similar but \pm glabrescent on adaxial surface; middle cauline-leaves progressively smaller, shortly petiolate, obtuse at the base, obtuse or subacute at the apex; upper cauline-leaves, small, sessile, obtuse at the base, subacute at the apex; all cauline leaves alternate; stem $40-160 \mathrm{~cm}$ of height, green to reddish-black, glabrescent but \pm persistently tomentose below; Inflorescence $25-60 \mathrm{~cm}$ of height, simple or sparingly branched at the base with short, sub-erect branches and then inflorescence narrowly pyramidal in outline; flowers arranged in clusters of pedicellate, compacted cymes (glomerules), \pm crowded at least above, consisting of $3-12$ flowers; bracts 3-7 $\times 2-4$ $\mathrm{mm}$, ovate-lanceolate, acute to acuminate, glabrescent; bracteoles present, similar to 

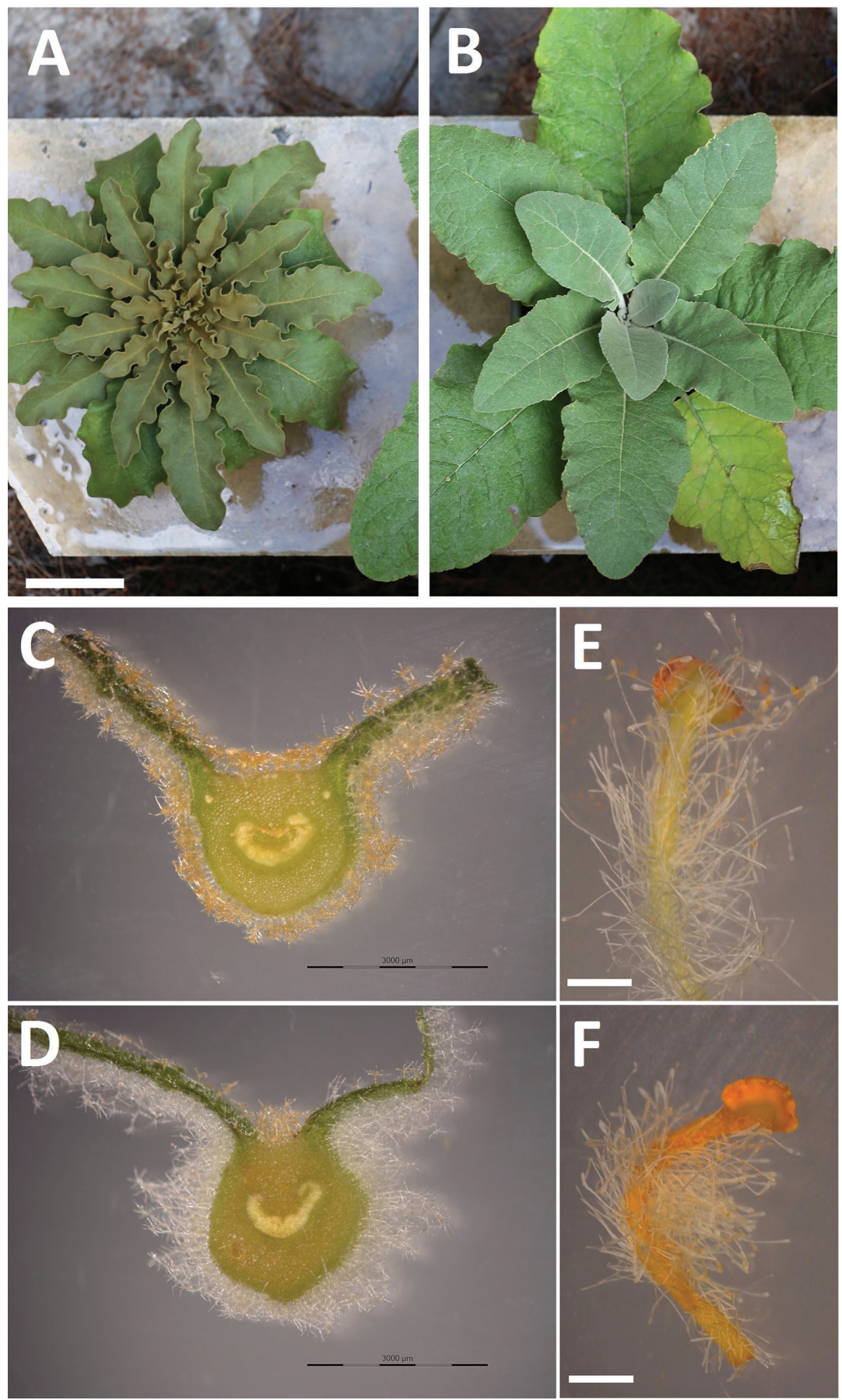

Figure 2. Comparative illustration of $V$. delphicum subsp. cervi and subsp. delphicum differential traits: A, C, E subsp. cervi B, D, F subsp. delphicum A, B first-year mature rosette-leaves of cultivated plants, bar $=10 \mathrm{~cm} \mathbf{C}$, $\mathbf{D}$ cross section of leaves indicating the shorter and darker indumentum of subsp. cervi, bars $=3 \mathrm{~mm} \mathbf{E}, \mathbf{F}$ anterior stamens, bars $=1 \mathrm{~mm}$; 
bracts but smaller; longer pedicels $3-8 \mathrm{~mm}$ of length, tomentose, \pm glabrescent; calyx divided almost to the base into 5 lanceolate to lanceolate-linear, acute segments, 3.5-6 $\times 1.1-1.7 \mathrm{~mm}$; abaxial surface of calyx tomentose, \pm glabrescent; corolla rotate, flat, $1.6-3.6 \mathrm{~cm}$ of diameter, light yellow, often with purple marks on the throat, with pellucid glands, divided to c. $3 / 4$ into 5 broadly-obovate, subequal lobes; abaxial surface of corolla partially tomentose, adaxial surface often ciliate near the throat, otherwise glabrous; tube of corolla \pm infundibuliform, 1-2.7 mm of length, $1.5-2.9 \mathrm{~mm}$ of diameter; stamens 5 , free, densely ciliate with white, clavate hairs which reach the connective of anthers; three posterior stamens 5-9.5 mm, two anterior stamens 7-12 mm; stamen filaments greenish-white, occasionally with a purple tinge; all five anthers reniform, mediofix, papillose on adaxial surface, $0.6-1.5 \mathrm{~mm}$; style tomentose at the base, 6-10 mm, clavate at the apex; stigma hemispherical; capsule (excl. rostrum) 3.5-7.5 $\times$ 3-5.4 mm, ovoid to broadly ovoid, densely tomentose on early development, later glabrescent, with a rostrum $1-1.5 \mathrm{~mm}$; seeds numerous, chestnut brown to dark brown, $0.7-1 \times 0.5-0.7 \mathrm{~mm}$, obpyramidal to ovoid-oblong, irregularly prismatic, faveolate with 3-7 pits in each longitudinal series.

Etymology. Name derives from the genitive of the Latin word "cervus" in reference to the red deer of the National Park which were often observed in the subspecies habitat. The popular animals are a considerable threat to their own Verbascum as they consume the young inflorescences.

\section{Verbascum delphicum Boiss. \& Heldr. subsp. delphicum var. filictorum Zografidis, var. nov.}

urn:Isid:ipni.org:names:77158534-1

Figure 3; Supplementary file 2.

Diagnosis. Variety filictorum differs from typical subsp. delphicum in that it produces sterile stems up to c. $80 \mathrm{~cm}$ of height instead of basal leaf-rosettes.

Type. GREECE. Ins. Evia. Above the settlement of Ag. Dimitrios, $38^{\circ} 06^{\prime} \mathrm{N}$, 24. $26^{\prime} \mathrm{E}$, in patches of Pteridium aquilinum, $500 \mathrm{~m}, 4$ July 2015, A. Zografidis 113. (Holotype: ATH, Isotype: ATHU)

Description. Polycarpic eglandular- and minutely glandular-hairy short-lived perennial herb —or less often monocarpic biennial— producing a well-branched taproot and a sterile, erect or ascending, terete, leafy stem in the first year of vegetative growth, followed by the production of an additional sterile stem and a terete flowering-stem in each of the succeeding few years of vegetative and reproductive growth. Eglandular hairs dendritic, $0.4-2 \mathrm{~mm}$ of length, more or less covering the whole aerial part of the plant; glandular hairs minute, sparse, present on leaves, bracts, bracteols and calyx segments, visible by microscopy; fully developed first-season leaves whitish- to yellowish- and softly-tomentose above, grayish-white and softly tomentose beneath; sterile stems up to $80 \mathrm{~cm}$ in height; fertile stems $40-180 \mathrm{~cm}$ of height, green to reddishblack, glabrescent but \pm persistently, tomentose below; lower cauline-leaves petiolate; 


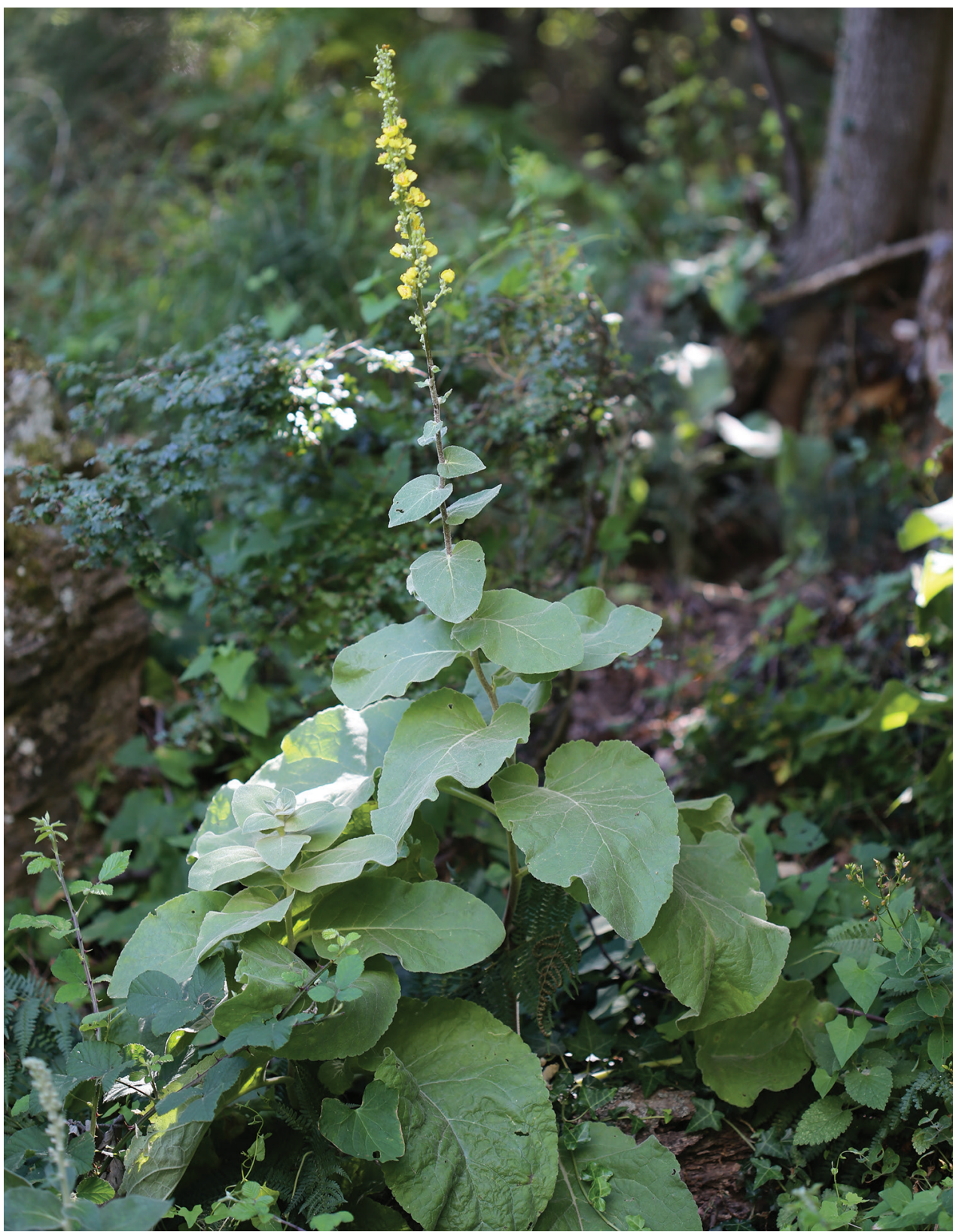

Figure 3. Verbascum delphicum subsp. delphicum var. filictorum Zografidis: Habit. A sterile stem is discernible next to the flowering stem.

petiole up to $15 \mathrm{~cm}$ of length; lamina ovate to widely ovate, $1.2-1.9$ of length to width ratio, obtuse-truncate to cordate at the base, crenate, obtuse at apex; larger leaf laminas $16-40 \times 11-24 \mathrm{~cm}$; middle cauline-leaves similar but progressively smaller and often subacute at the apex, shortly petiolate; upper cauline-leaves small, sessile, 
ovate-cordate, subacute at the apex; all cauline leaves alternate; Inflorescence 25-60 $\mathrm{cm}$ of height, simple or sparingly branched at the base with short, sub-erect branches and then inflorescence narrowly pyramidal in outline; flowers arranged in clusters of pedicellate, compacted cymes (glomerules), \pm crowded at least above, consisting of $3-12$ flowers; bracts 3-7 $\times 2-4 \mathrm{~mm}$, ovate to lanceolate, acute to acuminate or cuspidate, glabrescent; bracteoles present, similar to bracts but smaller; longer pedicels 4-10 $\mathrm{mm}$ of length, tomentose, \pm glabrescent; calyx divided almost to the base into 5 lanceolate to lanceolate-linear, acute segments, 3.5-6 × 1.1-1.7 mm; abaxial surface of calyx tomentose, \pm glabrescent; corolla rotate, flat, $1.5-2.8 \mathrm{~cm}$ of diameter, yellow, with or without indistinct purple marks on the throat, with pellucid glands, divided to c. 3/4 into 5 broadly-obovate, subequal lobes; abaxial surface of corolla partially tomentose, adaxial surface sometimes ciliate near the throat, otherwise glabrous; tube of corolla \pm infundibuliform, 1-2.3 mm of length, $1.5-2.2 \mathrm{~mm}$ of diameter; stamens 5 , free, ciliate with white, clavate hairs which reach the connective of all anthers or do not reach the connective of the anterior stamens; three posterior stamens $5-8 \mathrm{~mm}$, two anterior stamens $6-10 \mathrm{~mm}$; stamen filaments orange; all five anthers reniform, mediofix, papillose on adaxial surface, or glabrous on adaxial surface of the connective of anterior stamens, $0.8-1.4 \mathrm{~mm}$; style tomentose at the base, $6-9 \mathrm{~mm}$, slightly clavate at the apex; stigma hemispherical; capsule (excl. rostrum) 3.5-7 × 3-5 mm, ovoid to broadly ovoid, densely tomentose on early development, later glabrescent, with a rostrum 1-1.5 mm; seeds numerous, chestnut brown to dark brown, 0.7-1.1 $\times 0.5-0.7$ $\mathrm{mm}$, obpyramidal to ovoid-oblong, irregularly prismatic, faveolate with 4-8 pits in each longitudinal series.

Etymology. Name is in reference to the often abounding in ferns habitat of the variety.

V. delphicum specimens examined. subsp. cervi: GREECE. Attica: In regione abietina montis Parnethis, 5-18 June 1911, Tuntas s.n. (GB)

subsp. delphicum: GREECE. Ins. Evvia: In rupidus ad cacumen m. Delphi, 5000', 19 August 1948, Heldreich, 2040 (G-BOISS); In regione sylvatica \& superiore montis Dirphyis (Delphi hod.) usque ad cacumen, 3000'-5500' 31 July-5 August 1858, Heldreich 799 (K, P); Insula Evvia meridionalis, Montes Ocha, in valle infra Hagios Dimitrios, ca. 600 m, 21 May 1955, K. H. Rechinger, 17181 (W); Insula Evvia meridionalis, Montes Ocha, in querceto-castanetis vers us Kallianou, ca. 600 m, 22 May 1955, K. H. Rechinger, 17220 (W); Insula Evvia meridionalis, $3 \mathrm{~km}$ a promontorio Kaphireos occidentem versus, 22 June 1958, K. H. Rechinger, 18953 (W).

\section{Results and discussion}

The differences between $V$. delphicum subsp. cervi and subsp. delphicum are presented in Table 1, whereas a comparative illustration is presented in Figure 2. A three-year field survey of both insular and mainland populations and examination of cultivated plants confirmed the constancy of the distinctive features. Subspecies cervi is characterized by 
Table I. Diagnostic characteristics of $V$. delphicum subsp. cervi and subsp. delphicum. Numbers in brackets indicate mean and standard deviation values.

\begin{tabular}{l|c|c}
\hline & V. delphicum subsp. cervi & V. delphicum subsp. delphicum \\
\hline Life cycle & $\begin{array}{c}\text { Monocarpic biennial, rarely } \\
\text { polycarpic short-lived perennial }\end{array}$ & $\begin{array}{c}\text { Polycarpic short-lived perennial or } \\
\text { monocarpic biennial }\end{array}$ \\
\hline $\begin{array}{l}\text { Indumentum of first year mature } \\
\text { rosettes on adaxial surface of leaves }\end{array}$ & Yellowish to brownish, harsh & Grayish-white to yellowish, soft \\
\hline $\begin{array}{l}\text { Indumentum of rosette leaves on } \\
\text { abaxial surface }\end{array}$ & $\begin{array}{c}\text { Grayish-white or yellowish to } \\
\text { brownish, thin }\end{array}$ & Grayish-white, thick \\
\hline Dendritic hairs (mm) & $0.2-0.8$ & $0.4-2$ \\
\hline $\begin{array}{l}\text { Length to width ratio of leaf- } \\
\text { lamina (rosette leaves) }\end{array}$ & $1.5-3.7[2.5 \pm 0.5]$ & $1.2-1.9[1.6 \pm 0.2]$ \\
\hline Lamina of larger leaves, (cm) & $6-22[14.7 \pm 4.4] \times 3-11[6.2 \pm 1.9]$ & $16-40[26.6 \pm 7.1] \times 11-24[17 \pm 3.5]$ \\
\hline Base of lamina & Obtuse-cuneate & Obtuse-truncate to cordate \\
\hline Stamen filaments & Greenish-white & Orange \\
\hline $\begin{array}{l}\text { Hairs on connective of anterior } \\
\text { stamens (adaxial surface) }\end{array}$ & Present & Frequently absent \\
\hline
\end{tabular}

its smaller and more elongated leaves with the base of leaf-laminas obtuse to long-cuneate - vs. \pm truncate or even cordate in subsp. delphicum — and by a shorter, harsher and darker indumentum. Another significant character is the color of the stamen filaments: either greenish-white in subsp. cervi or deep-orange in subsp. delphicum. I note that this character is almost lost with drying. Life-cycle is an additional interesting trait. In his Flora Orientalis, Boissier has cited $V$. delphicum as a biennial herb (Boissier 1856), a vague conception which has been perpetuated in various floras ever since (Ferguson 1972; Raus 1986). Although biennial individuals are indeed found among its populations, the autonymous subspecies is more frequently a short-lived perennial herb as evidenced by the concomitant existence of the flowering stem and either of an additional leaf-rosette or of a previous-year withered infructenscence or of both on the same plants. On the other hand, subsp. cervi has clearly drifted towards the biennial life-cycle and very rarely do the plants exceed the usual two years lifespan -I have seen only two such individuals.

On Mt Parnitha and on the mountainous region of central Evvia - Mts Dirfi and Xirovouni- $V$. delphicum inhabits Greek-fir or mixed Abies-Castanea woodlands, flowers from early-mid-June to early-mid-August and matures seeds from July to August. On Mt Ochi of southern Evvia the species is found in open Castanea woodlands - Abies is absent from southern Evvia - or in sub-montate to montane, open shrublands dominated by thick patches of Pteridium aquilinum ferns. In these habitats of Mt Ochi, I have found that subsp. delphicum frequently produce sterile stems instead of basal leaf rosettes; the unusual trait gives a quite distinctive appearance to the plants but apart from it they are indistinguishable from typical individuals that grow in proximity. I propose this taxon to be classified as a new variety of subsp. delphicum (Figure 3 and Supplementary file 2). The variety might have evolved from the competition for sunlight inside the dense patches of ferns of these habitats, whereas I have never found 
it in central Evvia — not even in the shadier spots where subsp. delphicum produces the typical basal rosettes.

Murbeck's assumption that typical $V$. delphicum existed on Mt Parnitha was based on the following material he cited in his monograph: i) a collection by Heldreich — "Parnes, reg. abiet. occid., leg. HELDREICH 1854, n. 2902 [Hb. Berl.]"- even though Heldreich himself never reported $V$. delphicum from mainland Greece and the date of the collection, which has unfortunately been destroyed during World War II (Th. Raus, personal communication, 27 August 2015), precedes by two years that of the original description of the species; ii) three collections by collector Bassilios Tuntas _-"Parnes, reg. abiet., occid., leg. TUNTAS 5/7/1911, n. 1247 [Hb. Hal.; Hayek].- Mt Parnes, prope cacumen, leg. TUNTAS 21/7/1907, n. 356 [Hb. Hal.]; 13/6/1909, n. 810 [Hb. Hal.]" - which, however, were not found either in WU-Generale, WU-HalácsyGraecum or WU-Halácsy-Europaeum (W. Till, personal communication, 15 March 2016). Perhaps the only surviving voucher is kept in the Gothenburg Herbarium and likely corresponds to the aforementioned n. 1247 specimen of the collector, although the serial number is missing. Nevertheless, on the sheet there is a label with Murbeck's name and handwriting that states " $V$. delphicum". Having seen the specimen I have no doubt it represents subsp. cervi on account of the characteristic small basal leaves with an obtuse-cuneate base and the short indumentum. It is interesting to note that the aforementioned specimen includes the whole aerial part of a plant arranged on a single sheet, which is actually feasible for a medium individual of subsp. cervi - e.g., see the Holotype, Supplementary file 1. On the contrary, a medium individual of subsp. delphicum is impossible to completely fit on a voucher sheet because the basal leaves are too big. I conclude that on Mt Parnitha there exists a single infraspecific taxon of $V$. delphicum, namely subsp. cervi, allopatric to the insular subsp. delphicum which is confined to Evvia. The species had not been collected from the mainland for almost a century, but its existence was confirmed by a recent floristic study on the mountain (Aplada et al. 2007), (E. Aplada, personal communication 1 September 2016). Other reports of $V$. delphicum from the mainland - from the Peloponnese cited in (Dimopoulos et al. 2013) or from Mt Pendeli cited in (Vladimirov et al. 2012) - are in error (Th. Raus, and K. Polymenakos, personal communications respectively). The distribution map of $V$. delphicum is presented in Figure 4.

\section{Suggested conservational status}

$V$. delphicum subsp. cervi is restricted to the core of the National Park of Mt Parnitha where it apparently constitutes a single, fragmented population within an area of occupancy of less than $1 \mathrm{~km}^{2}$ and a total population size of no more than 50 mature individuals (August 2016). The alarmingly rare new taxon has suffered habitat loss with the devastating fire of 2007 on the mountain and is now under direct threat by the overpopulated deer of the National Park which consume the developing inflorescences; the bitten plants respond by producing a few new small flowering shoots but seed yield is expected to be 


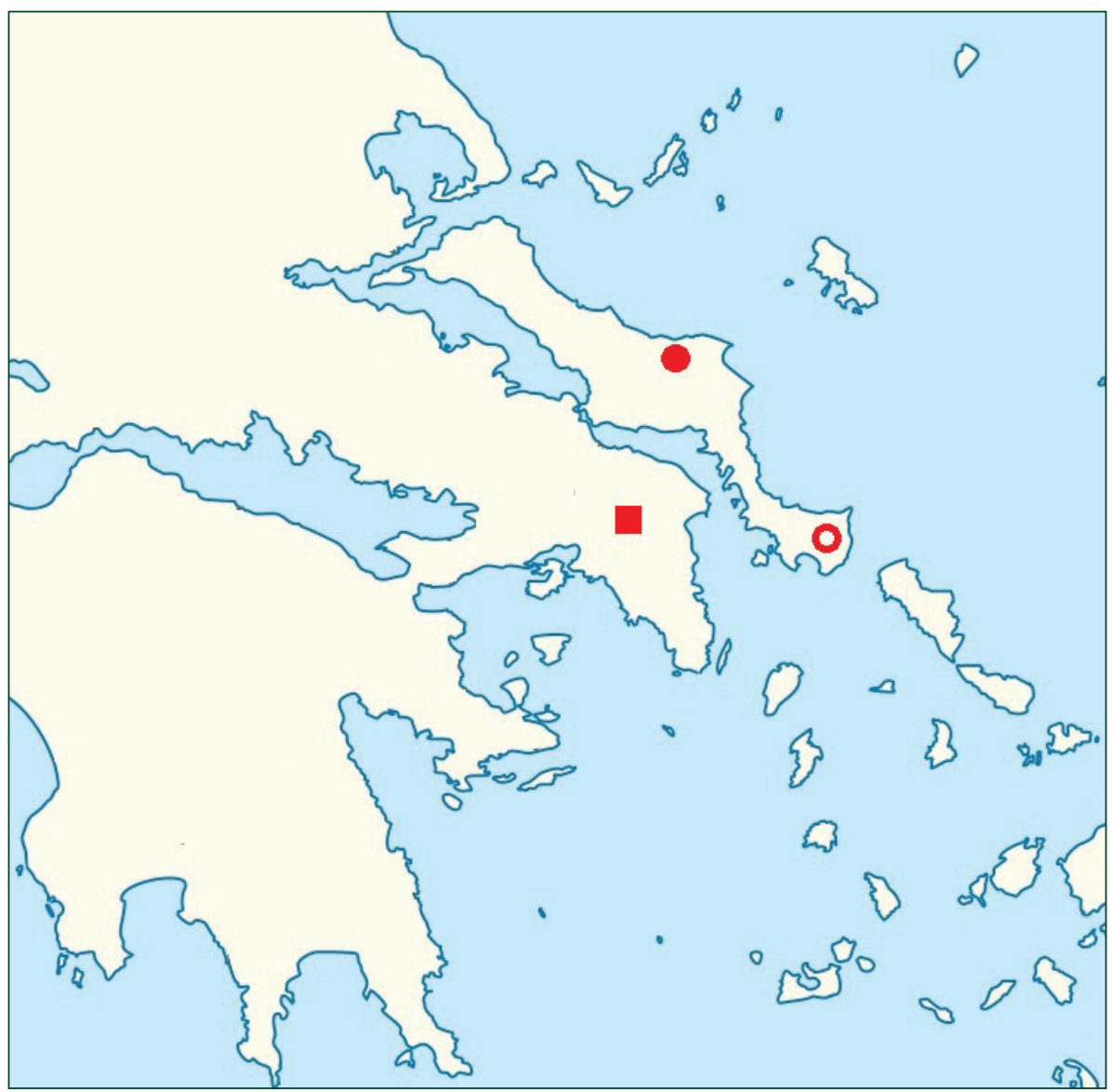

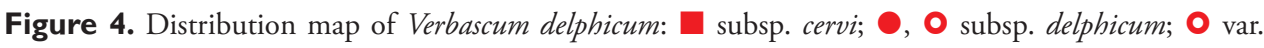
filictorum.

severely affected. Importantly, the population size of $V$. delphicum subsp. cervi has been reduced about $20 \%$ over the last three years and the taxon is apparently critically endangered according to IUCN Red list criteria C(2a(i,ii)) and D(1) (IUCN 2001).

\section{Comments on taxonomic affinities and phytogeography}

Considering the recent radiation in the genus Verbascum (Ghahremaninejad et al. 2014) and the strong phytogeographic connection between Ins. Evvia and Sterea Ellas (Trigas 2003), it is reasonable to assume that $V$. delphicum subsp. cervi represents a neoendemic taxon that has diverged from the insular subspecies through the process of allopatric subspeciation. On the other hand, the infrageneric relationships of $V$. delphicum are more difficult to infer. In particular, Murbeck places $V$. delphicum under Sect. Bothrosperma Murb., Subsect. Fasciculata Murb., B. Isandra Franch., p. p., a. 
Bracteolata Murb., $\alpha$ Umbellulifera Murb., 1. Adenanthera Murb. and further groups it with the widespread in the Balkans $V$. banaticum Schrad. on account of the white stamen-hairs and the relatively long pedicels. However, the two species are very different and only doubtfully closely related $-V$. banaticum is an eglandular herb with lobed and pinnatisect at the base of the lamina rosette-leaves, freely branched, leafy, lax inflorescences and has smaller all flower parts and capsule. Rather I suspect that Adenanthera -i.e. having papillate connective of the anthers of the anterior stamensis a non-monophyletic trait and that $V$. delphicum is actually more closely related to some Leianthera Murb. -i.e. with glabrous connective- species of the centered but not restricted to the Balkans group of V. nigrum L., V. chaixii Vill., V. lanatum Schrad. and $V$. glabratrum Friv. These species show considerable resemblance to $V$. delphicum with respect to general leaf morphology, indumentum and habit. Moreover, additionally to their glabrous connective of anterior stamens, these species all differ from $V$. delphicum in the purple stamen-hairs and in the more or less striate stems. I should also note at this point that the connective of the anterior stamens of $V$. delphicum is often glabrous too and this is particularly evident for subsp. delphicum - Figure $2 \mathrm{~F}$ shows one such stamen with the hairs not found on the connective. Intriguingly, $V$. delphicum also shows considerable phenetic resemblance with two Asiatic species, namely $V$. discolor Murb. from the Amanus Mountains and V. antitauricum Hub.-Mor. from the Anti-Taurus mountains, both of south-central Turkey. $V$. discolor is generally a more glabrous plant than $V$. delphicum with glabrous connective of anterior stamens, glabrous outer surface of the corolla and a more branched and laxer inflorescence. $V$. antitauricum, similarly to $V$. delphicum has either papillate or glabrous connective of anterior stamens but has bicolored stamen-hairs, glabrous corollas on the outer surface, more or less shorter pedicels and it is eglandular. In any case, the differences between $V$. delphicum and the Turkish species are not more pronounced than those between $V$. delphicum and the aforementioned Balkan species — compared individually — and thus additional data from molecular phylogenetics and/or cytological studies are needed for clarifying the topic of $V$. delphicum infrageneric affinities.

\section{Conclusions}

Both infraspecific taxa of $V$. delphicum described in this study are distinct and easily recognized, whereas the species closest relative remains unknown. Subspecies cervi is apparently a critically endangered taxon.

\section{Acknowledgments}

I am grateful to: P. Koubetsos and K. Polymenakos for the useful discussions on interesting Verbasca of Mt Parnitha; Th. Constantinidis and P. Bareka for their notes on speciation; P. Livanos and S. Samaropoulou for the technical aid and their welcoming smile. 


\section{References}

AI-Hemaid FMA (2001) Notes on Verbascum L., from Saudi Arabia with description of eight new species. Pakistan Journal of Botany 33(4): 315-328.

Aplada E, Georgiadis Th, Tiniakou A, Theocharopoulos M (2007) Phytogeography and ecological evaluation of the flora and vegetation of Mt Parnitha (Attica, Greece). Edinburgh Journal of Botany 64(2): 185-207. doi: 10.1017/S096042860700087X

Aytaç Z, Duman H (2012) Verbascum hasbenlii (Scrophulariaceae), a new species from Turkey. Turkish Journal of Botany 36: 322-327. doi: 10.3906/bot-1108-9

Bani B, Adigüzel N, Karavelioğullari FA (2010) Verbascum turcicum (Scrophulariaceae), a new species from Turkey. Annales Botanici Fennici 47: 489-492. doi: 10.5735/085.047.0608

Boissier E (1856) Verbascum delphicum Boiss. \& Heldr. Diagnoses plantarum Orientalium novarum ser 2 no 3. Apud B. Herrmann, Lipsiae. http://bibdigital.rjb.csic.es/ing/Libro. php? Libro $=1417 \&$ Pagina $=148$

Çeçen Ö, Karavelioğulları FA, Ünal A (2015) Verbascum misirdalianum (Scrophulariaceae), a new species from central Anatolia, Turkey. Phytotaxa 217(1): 96-99. doi: 10.11646/ phytotaxa.217.1.10

Davis PH (1951) Three New Species from the Nearer East. Notes from the Royal Botanic Garden Edinburgh 21(1): 46-52.

Davis PH (1952) Additamenta ad Flora Anatoliae: III. Notes from the Royal Botanic Garden Edinburgh 21(2): 61-98.

Dimopoulos P, Raus Th, Bergmeier E, Constantinidis Th, Iatrou G, Kokkini S, Strid A, Tzanoudakis D (2013) Vascular plants of Greece: An annotated checklist. Botanischer Garten und Botanisches Museum Berlin-Dahlem, Berlin; Hellenic Botanical Society, Athens.

Ferguson IK (1972) Verbascum L. In: Tutin TG, Heywood VH, Burges NA, Moore DM, Valentine DH, Walters SM, Webb DA (Eds) Flora Europaea Vol 3. Cambridge University Press, 205-216.

Firat M (2015) Verbascum kurdistanicum (Scrophulariaceae), a new species from Hakkâri, Turkey. PhytoKeys 52: 89-94. doi: 10.3897/phytokeys.52.5188

Fischer E (2004) Scrophulariaceae. In: Kubitzki K, Kadereit J (Eds) Flowering Plants - Dicotyledons: Lamiales The Families and Genera of Vascular Plants VII. Springer, 333-432. doi: 10.1007/978-3-642-18617-2_21

Ghahremaninejad F, Riahi M, Babaei M, Attar F, Beh set L, Sonboli A (2014) Monophyly of Verbascum (Scrophularieae : Scrophulariaceae): evidence from nuclear and plastid phylogenetic analyses. Australian Journal of Botany 62: 638-646. doi: 10.1071/BT14159

Greuter W, Rechinger KH (1972) Verbascum spathulisepalum (Scrophulariaceae) eine neue Art aus Nordost-Griechenland. Botaniska Notiser 125: 494-497.

Huber-Morath A (1939) Über orientalische Verbascum- und Celsia-Arten. Feddes repertorium specierum novarum regni vegetabilis 46: 169-184.

Huber-Morath A (1949) Studien über anatolische Verbascum und Celsia arten Candollea 12: 187-218.

Huber-Morath A (1955) Verbreitung der Gattungen Verbascum, Celsia und Straurophragma im Orient. BAUHINIA 1(1): 1-83. 
Huber-Morath A (1960) Novitiae Florae Anatolicae V. Gattung Verbascum L. BAUHINIA 1(3): 335-349.

Huber-Morath A (1965) Bearbeitung orientalischer Verbasceen, 1961-1964. BAUHINIA 2(3): 239-259.

Huber-Morath A (1967) Novitiae Florae Anatolicae VIII. BAUHINIA 3(2): 311-326.

Huber-Morath A (1971) Die türkischen Verbasceen. Denkschriften der Schweizerischen Naturforschenden Gesellschaft 87: 1-166.

Huber-Morath A (1973) Verbascum L. s.l. (incl. Celsia L. et Staurophragma Fisch. \& Mey.). BAUHINIA 5(1): 7-16.

Huber-Morath A (1974) Novitiae Florae Anatolicae X. BAUHINIA 5(2): 101-102.

Huber-Morath A (1975) Zwei neue Verbascum-Arten aus Iran. BAUHINIA 5(3): 147-149.

Huber-Morath A (1976) Novitiae Florae Anatolicae XI. BAUHINIA 5(4): 231-232.

Huber-Morath A (1978) Verbascum L. In: Davis P (Ed) Flora of Turkey and the East Aegean Islands Vol 6. Edinburgh University Press, Edinburgh, 461-603.

Huber-Morath A (1979) Novitiae Florae Anatolicae XIII. BAUHINIA 6(3): 369-374.

Huber-Morath A (1981) Novitiae Florae Anatolicae XIV. BAUHINIA 7(2): 77-80.

Huber-Morath A (1983) Novitiae Florae Anatolicae XVI. BAUHINIA 7(4): 269-271.

IUCN (2001) IUCN Red List Categories and Criteria: Version 3.1: IUCN Species Survival Commission. IUCN, Gland, Switzerland \& Cambridge, UK.

Karavelioğullari FA (2015) New species and new hybrid of genus Verbascum L. (Verbascum mecit-vuralii Karavel. Verbascum x ersin-yücelii Karavel.) from Turkey. Biological Diversity and Conservation 8: 78-82.

Karavelioğullari FA, Çelik S, Başer B, Yavru A (2011) Verbascum ergin-hamzaoglui (Scrophulariaceae), a new species from South Anatolia, Turkey. Turkish Journal of Botany 35: 275-283. doi: 10.3906/bot-1003-51

Karavelioğullari FA, Duran A, Hamzaoğlu E (2004) Verbascum tuna-ekimii (Scrophulariaceae), a new species from Turkey. Annales Botanici Fennici 41: 227-231.

Karavelioğulları FA, Ocak A, Ekici M, Cabi E (2009) Verbascum eskisehirensis sp. nov. (Scrophulariaceae) from central Anatolia, Turkey. Nordic Journal of Botany 27(3): 222-227. doi: 10.1111/j.1756-1051.2008.00250.x

Karavelioğullari FA, Uzunhisarcikli ME, Çelik S (2008) Verbascum ozturkii (Scrophulariaceae) a new species form East Anatolia, Turkey. Pakistan Journal of Botany 40(4): 1595-1599.

Karavelioğullari FA, Yüce E, Başer B (2014) Verbascum duzgunbabadagensis (Scrophulariaceae), a new species from eastern Anatolia, Turkey. Phytotaxa 181(1): 47-53. doi: 10.11646/ phytotaxa.181.1.3

Kaynak G, Daşkin R, Yilmaz Ö, Erdoğan E (2006) Verbascum yurtkuranianum (Scrophulariaceae), a new species from northwest Anatolia, Turkey. Annales Botanici Fennici 43: 456-459.

Murbeck S (1925) Monographie der Gattung Celsia Lunds Universitets årsskrift. n. f., avd. 2.

Murbeck S (1933) Monographie der Gattung Verbascum. Lunds Universitets årsskrift. n. f., avd. 2.

Murbeck S (1936) Nachträge zur Monographie der Gattung Verbascum. Lunds Universitets årsskrift. n. f., avd. 2. 
Murbeck S (1939) Weitere Studien über die Gattungen Verbascum und Celsia. Lunds Universitets årsskrift. n. f., avd. 2.

Oxelman B, Kornhall P, Olmstead RG, Bremer B (2005) Further disintegration of Scrophulariaceae. Taxon 54(2): 411-425. doi: 10.2307/25065369

Parolly G, Eren Ö (2008) Verbascum haraldi-adnani (Scrophulariaceae), a new chasmophytic species from SW Anatolia, Turkey. Willdenowia 38: 127-134. doi: 10.3372/wi.38.38107

Parolly G, Tan K (2007) Verbascum lindae (Scrophulariaceae), a new species from SW Anatolia, Turkey. Willdenowia 37: 277-282. doi: 10.3372/wi.37.37116

Ranjbar M, Nouri S (2015) Verbascum albidiflorum (Scrophulariaceae), a new species from W Iran Willdenowia 45: 147-155. doi: 10.3372/wi.45.45115

Raus Th (1986) Verbascum L. . In: Strid A, Tan K (Eds) Mountain Flora of Greece Vol 2. Edinburgh University Press, 170-188.

Sotoodeh A, Attar F, Civeyrel L (2015) Verbascum shahsavarensis (Scrophulariaceae), a new species for Flora of Iran. Phytotaxa 203(1): 76-80. doi: 10.11646/phytotaxa.203.1.8

Sotoodeh A, Attar F, Civeyrel L (2016) A new species of Verbascum L. (Scrophulariaceae) from the Gilan province (Iran), based on morphological and molecular evidences. Adansonia 38(1): 127-132. doi: 10.5252/a2016n1a9

Stefanova-Gateva B (1979) Zwei neue Arten der Gattung Verbascum in Bulgarien. Feddes Repertorium 90(7-8): 407-408. doi: 10.1002/fedr.19790900704

Trigas P (2003) Contribution to the study of the endemism of the flora of the island of Evvia (W Aegean, Greece). PhD Thesis, University of Patras, Patras.

Vladimirov V, Dane F, Tan K (2012) New floristic records in the Balkans: 20. Phytologia Balcanica 18(3): 333-373. 


\section{Supplementary material I}

Verbascum delphicum subsp. cervi Zografidis subsp. nov., holotype.

Authors: Aris Zografidis

Data type: JPEG file

Copyright notice: This dataset is made available under the Open Database License (http://opendatacommons.org/licenses/odbl/1.0/). The Open Database License $(\mathrm{ODbL})$ is a license agreement intended to allow users to freely share, modify, and use this Dataset while maintaining this same freedom for others, provided that the original source and author(s) are credited.

\section{Supplementary material 2}

Verbascum delphicum subsp. delphicum var. filictorum Zografidis var. nov., holotype. Authors: Aris Zografidis

Data type: JPEG file

Copyright notice: This dataset is made available under the Open Database License (http://opendatacommons.org/licenses/odbl/1.0/). The Open Database License $(\mathrm{ODbL})$ is a license agreement intended to allow users to freely share, modify, and use this Dataset while maintaining this same freedom for others, provided that the original source and author(s) are credited. 